\title{
PENGARUH INSENTIF TERHADAP DISIPLIN KERJA PEGAWAI DINAS TENAGA KERJA KABUPATEN BANDUNG
}

\author{
The Influence of Incentive Provision on the Labor Discipline Employees at \\ Dinas Tenaga Kerja Kabupaten Bandung
}

\author{
Rizca Amalia, Adman
}

Email: riska.amaliakyu@gmail.com; adman@upi.edu

\begin{abstract}
ABSTRAK
Permasalahan yang dikaji dalam penelitian ini adalah mengenai tingkat disiplin kerja pegawai Dinas Tenaga Kerja Kabupaten Bandung. Hal tersebut ditandai dengan masih rendahnya absebsi kehadiran pegawai. Dari fenomena tersebut dapat dikatakan Dinas Tenaga Kerja Kabupaten Bandung belum sepenuhya mewujudkan tujuan organisasi yang dikehendaki. Tujuan dalam penelitian ini adalah untuk memperoleh gambaran efektivitas insentif, gambaran mengenai tingkat disiplin kerja pegawai dan untuk mengetahui seberapa besar pengaruh insentif terhadap disiplin kerja pegawai Dinas Tenaga Kerja Kabupaten Bandung.

Metode penelitian yang digunakan dalam penelitian ini adalah metode survei eksplanasi dengan menggunakan teknik analisis data deskriptif inferensial, adapun teknik pengumpulan data dilakukan dengan cara penyebaran angket dengan menggunakan skala likert, yang dikumpulkan dari responden dengan ukuran populasi 54 orang pegawai Dinas Tenaga Kerja Kabupaten Bandung. Analisis data yang digunakan dalam penelitian ini adalah regresi sederhana.

Berdasarkan hasil penelitian ini diperoleh informasi bahwa insentif dan disiplin kerja Dinas Tenaga Kerja Kabupaten Bandung berada pada kategori cukup/sedang. Dari hasil uji hipotesis diperoleh bahwa efektivitas insentif memiliki pengaruh positif dan signifikan terhadap disiplin kerja. Namun demikian, disiplin kerja pegawai Dinas Tenaga Kerja Kabupaten Bandung tidak hanya dipengaruhi oleh insentif saja, melainkan ada faktor lainnya yang juga berpengaruh, tetapi tidak dikaji dalam penelitian ini.
\end{abstract}

\section{Kata Kunci : insentif, disiplin kerja}

\section{ABSTRACT}

The present study focused on the labor discipline of the employees of Dinas Tenaga Kerja Kabupaten Bandung, which wasshown by low presence of the employees. From this phenomenon, it can be said that Dinas Tenaga Kerja Kabupaten Bandung had not fully achieved the expected organizational goals. The purpose of this study was to examine the effectiveness of incentive provision, the employee's labor discipline and the degree of the influence of incentive provision on the labor discipline of the employees of Dinas Tenaga Kerja Kabupaten Bandung. 
This study employed a survey method of explanation with data analysis and inferential descriptive techniques. The technique used to collect the data were questionnaires with Likert scales distributed and collected from respondents with a population of 39 employees of Dinas Tenaga Kerja Kabupaten Bandung. As for data analysis, a simple regression technique was used.

From the results of this research, it was revealed that incentive provision and the labor discipline of the employees of Dinas Tenaga Kerja Kabupaten Bandung are quite effective. From results of the hypotheses testing, it was found out that incentive provision had positive and significant influence on the labor discipline. Nevertheless, the discipline of the employees of Dinas Tenaga Kerja Kabupaten Bandung was not only influenced by incentive provision, but also by other factors which were not investigated in this study.

Keywords: incentive provision, labor discipline

\section{LATAR BELAKANG}

Tenaga kerja atau pegawai merupakan sumber daya manusia yang sangat penting dalam suatu perusahaan, karena pegawai adalah modal utama bagi suatu perusahaan tanpa adanya pegawai perusahaan tidak akan berjalan dengan baik. Sumber daya manusia yang dimaksudkan disini adalah Pegawai Negri Sipil (PNS). PNS memiliki peranan penting penunjang keberhasilan suatu instansi pemerintahan yaitu dalam melaksanakan tugas-tugas pemerintah maupun tugas pembangunan.

Dinas Tenaga Kerja Kabupaten Bandung merupakan lembaga dinas daerah Kabupaten Bandung yang mengemban tugas di bidang ketenaga kerjaan. Disiplin kerja merupakan salah satu indikator untuk dapat membuat Dinas Tenaga Tenaga Kerja ini dapat bertahan dan mampu bersaing. Oleh karena itu, sumber daya manusia yang potensial dan berkualitas salah satu unsur yang harus dimiliki oleh sumber daya manusia (pegawai) adalah disiplin. Hal ini sesuai dengan pendapat Hasibuan (1997:212) bahwa kedisiplinan merupakan fungsi operatif manajemen sumber daya manusia yang terpenting, karena semakin baik disiplin pegawai, maka semakin tinggi prestasi kerja yang yang dapat dicapainya.

Gambaran umum rendahnya Masalah kedisiplian tersebut bisa dilihat dari beberapa indikator seperti tingkat kehadiran, tingkat ketaatan pada standar kerja, dan tingkat peraturan kerja yang masih rendah. Jika dibiarkan, masalah tersebut akan menghambat tercapainya efektivitas organisasi sehingga akan menghambat pula pencapaian tujuan yang telah ditetapkan sebelumnya. 
Sedangkan faktor lain yang dapat menunjukkan menurunnya tingkat disiplin salah satunya adalah absensi pegawai. Berikut gambar ketidak hadiran pegawai Dinas Tenaga Kerja Kabupaten Bandung.

Gambar 1.1

Data Absensi Pegawai Dinas Tenaga Kerja Kabupaten Bandung Periode Tahun 2009-2013

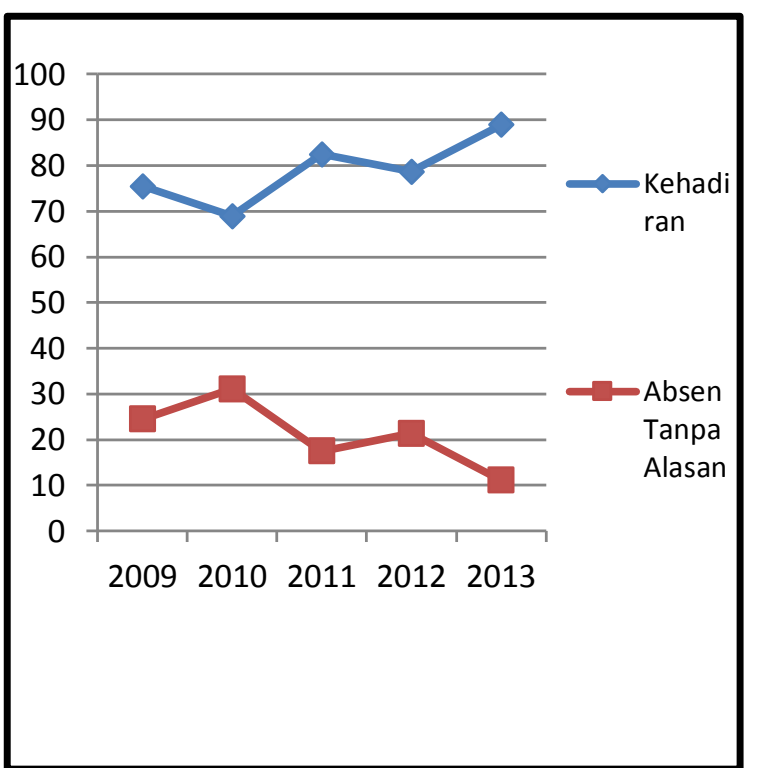

\begin{tabular}{|l|c|c|c|c|c|c|c|c|c|c|c|c||}
\hline \multirow{2}{*}{ Sanksi } & \multicolumn{9}{|c|}{ Bulan } \\
\cline { 2 - 15 } & Jan & Feb & Mar & Apr & Mei & Jun & Jul & Ags & Sep & Okt & Nov & Des \\
\hline Teguran Lisan & 4 & 2 & - & - & - & - & 3 & 2 & 5 & 4 & - & - \\
\hline $\begin{array}{l}\text { Teguran } \\
\text { Tertulis }\end{array}$ & - & - & - & 3 & 4 & 2 & - & - & - & - & 2 & 3 \\
\hline $\begin{array}{l}\text { Panggilan } \\
\text { Dinas }\end{array}$ & - & - & 2 & - & - & - & - & - & - & - & - & - \\
\hline $\begin{array}{l}\text { Penundaan } \\
\text { Kenaikan Gaji } \\
\begin{array}{l}\text { Berkala } \\
\text { (KGB) }\end{array}\end{array}$ & - & - & - & - & - & - & - & - & - & - & - & - \\
\hline $\begin{array}{l}\text { Penundaan } \\
\text { Kenaikan } \\
\text { Pangkat }\end{array}$ & - & - & - & - & - & - & - & - & - & - & - & - \\
\hline $\begin{array}{l}\text { Penurunan } \\
\text { Pangkat }\end{array}$ & - & - & - & - & - & - & - & - & - & - & - & - \\
\hline $\begin{array}{l}\text { Pembebasan } \\
\text { dari Jabatan }\end{array}$ & - & - & - & - & - & - & - & - & - & - & - & - \\
\hline Pemberhentian & - & - & - & - & - & - & - & - & - & - & - & - \\
\hline $\begin{array}{l}\text { Jumlah } \\
\text { Karyawan }\end{array}$ & 62 & 62 & 60 & 54 & 54 & 54 & 54 & 54 & 54 & 54 & 54 & 54 \\
\hline \begin{tabular}{l} 
Jumlah \\
\hline Presentase
\end{tabular} & 4 & 2 & 2 & 3 & 4 & 2 & 3 & 2 & 5 & 4 & 2 & 3 \\
\hline \hline
\end{tabular}

Sumber: Dinas Tenaga Kerja Kabupaten Bandung

Berdasarkan gambar di atas dapat diketahui bahwa tingkat kehadiran pegawai Dinas Tenaga Kerja Kabupaten Bandung mengalami fluktuatif setiap tahunnya. Hal ini dilihat dari rata-rata perbandingan setiap tahunnya dari 2009 sampai 2013, dimana tingkat ketidak hadiran pegawai pada tahun 2009 mencapai 24,49\%. Pada tahun 2010 mengalami kenaikan ketidakhadiran sebesar 31,07 \%, dan pada tahun 2011 mengalami penurunan absen mencapai 17,51 \%. Pada tahun 2012 mengalami sedikit kenaikan absen mencapai 23,41\% dan pada tahun selanjutnya yaitu 2013 mengalami penurunan absen sebesar 13,08 $\%$.

Hal ini menunjukkan masih kurangnya rasa disiplin yang dimiliki oleh para pegawai dengan bertambahnya ketidakhadiran tersebut akan mengakibatkan menumpuknya tugas yang belum terselesaikan tepat waktu, dan juga tingkat kehadiran yang ditetapkan di Dinas Tenaga kerja haruslah mencapai $100 \%$.

Selain daripada tingkat absensi untuk mengukur kedisiplinan pegawai juga dapat dilihat dari gambaran umum kemangkiran pegawai Dinas Tenaga Kerja Kab. Bandung sebagaimana dalam tabel dibawah ini: 
Tabel 1.1

Data Kemangkiran Pegawai Dinas Tenaga Kerja Kabupaten Bandung

Periode Januari-Desember 2013

Sumber: Dinas Tenaga Kerja Kabupaten Bandung

Berdasarkan tabel 1.1 dapat dilihat bahwa tingkat kemangkiran pegawai Dinas Tenaga Kerja Kabupaten Bandung setiap bulannya mengalami kenaikan dan penurunan. Hal tersebut mengakibatkan ketidakefektifan yang akan mempengaruhi cara kerja, waktu kerja dan hasil kerja. untuk lebih jelas dapat dilihat pada gambar berikut.

\section{Gambar 1.2 \\ Data Kemangkiran Pegawai Dinas Tenaga Kerja Kabupten Bandung Periode Januari-Desember 2013}

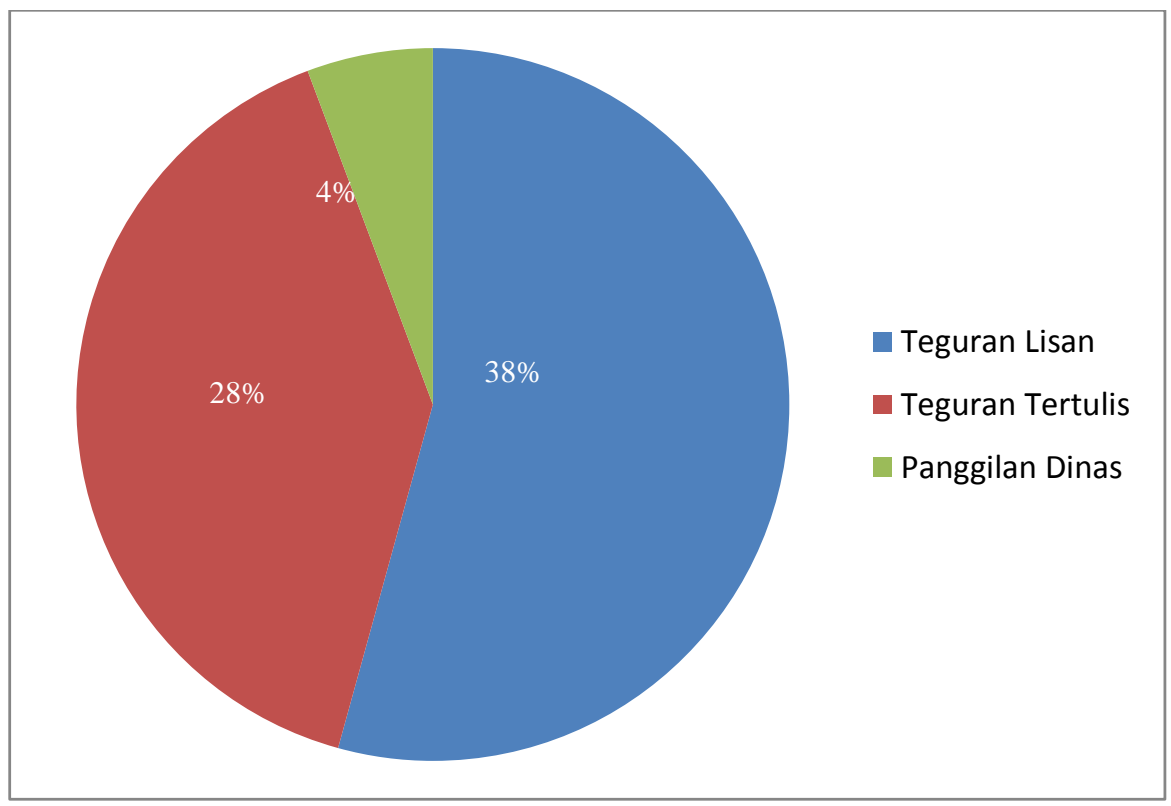

Pada gambar di atas menunjukkan bahwa tingkat peraturan pegawai Dinas Tenaga Kerja Kabupaten Bandung pada sanksi teguran tertulis memperoleh nilai presentase tertinggi yaitu sebesar 38\%, teguran lisan 28\%, dan Panggilan dinas hanya memperoleh nilai sebesar $4 \%$. Hal tersebut menggambarkan adanya penurunan disiplin yang terjadi pada para pegawai. Berdasarkan gambar diatas dapat diasumsikan bahwa telah terjadi ketidakpuasankerja pegawai ditinjau dari disiplin kerja pegawai.

Banyak perusahaan meyakini bahwa terciptanya disiplin kerja yang relatif tinggi dipengaruhi oleh balas jasa atau insentif yang diberikan oleh perusahaan. Pemberian insentif diharapkan mampu mengatasi berbagai permasalahan di tempat kerja yang semakin kompleks seperti rendahnya kinerja dan kedisiplinan pegawai, kurangnya minat kerena tidak adanya tambahan gaji pokok. Pengupayaan insentif yang besarnya proposional dan bersifat progresif sesuai dengan jenjang karir diyakini mampu memacu 
kinerja para keryawan agar selalu berada pada tingkat tertinggi (optimal) dalam mengembangkan kemampuan yang dimiliki.

Fenomena di atas dapat dijadikan acuan mengenai diberikannya perangsang finansial yang melibihi upah dan gaji pokok (insentif) sebagai salahsatu alternatif yang baik dalam proses menigkatkan motivasi kerja. Sehingga dalam dirinya tumbuh kesadaran akan mau untuk disipin dalam melaksanakan pekerjaanya seefektivitas dan sefisien mungkin, yang pada akhirnya akan berpengaruh positif terhadap kemajuan perusahaan. Seperti yang dikemukakan oleh Tani Handoko dalam (Mangkunegara, 2005:89) "Tujuan insentif adalah untuk meningkatkan motivasi pegawai dalam upaya mencapai tujuan-tujuan organisasi”.

Pendekatan yang digunakan untuk memecahkan masalah penelitilian ini adalah pendekatan psikologi tentang perilaku, khususnya teori perilaku organisasi. Gibson (1997:15) dalam Sambas Ali Muhidin (2007:61-62) mengemukakan bahwa "Konsep dasar psikologi pada dasarnya dilandasi oleh proses-proses psikis pada diri individu, atau organisme di dalam lingkungan tertentu". Proses inetraksi akan selalu terjadi dimanapun, terutama dalam sebuah organisasi. Interaksi tersebut dapat menimbulkan perilaku-perilaku tertentu pada organisasi salah satunya adalah perilaku individu. Kajian mengenai perilaku individudipelajari dalam perilaku organisasi dan untuk memahami perilaku dalam organisasi adalah dengan menggunakan stimulus-respon. Fred Luthan (dalam Vivin Andhika, 2006:22) menjelaskan bahwa: "Akar teori ini dapat ditelusuri karya Ivan Pvalov dan Jhon B. Watson yang mengungkapkan bahwa teori behavioristik dalam psikologi menekankan pentingnya memahami perilaku yang dapat diamati pemikiran yang sukar dipahami. Mereka menggunakan eksperimen classsical conditioning untuk merumuskan penjelasan stimulus-respon (S-R) perilaku manusia”. berikut:

Kerangka konseptual psikologi tentang perilaku individu dapat diterangkan sebagai

Gambar 1.3

\section{Kerangka Konseptual}

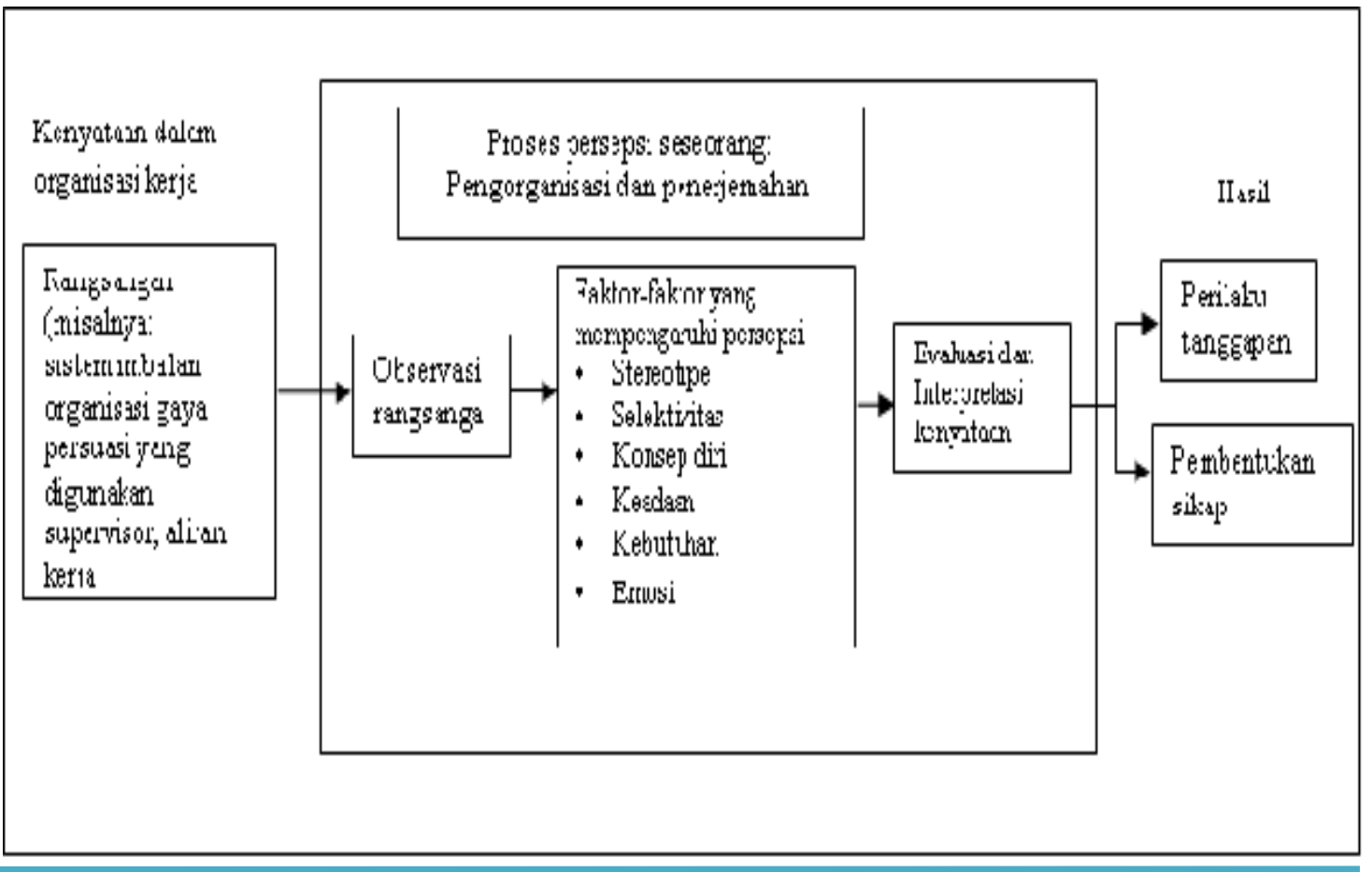


Kerangka konseptual di atas menunjukkan dimana ransangan tersebut yaitu insentif mewakili segala sesuatu yang nyata terdapat di dalam organisasi kerja. Selanjutnya, dilakukan proses persepsi berupa pengorganisasian dan penerjemahan. Seorang individu akan mulai berinteraksi terhdap ransangan tersebut dan akan menimbulkan persepsi mengenai ransangan tersebut menjadi sebuah persepsi, seorang individu akan mengobservasi terlebih dahulu ransangan yang masuk. Selanjutnya seorang individu akan mempertimbangkan faktor yang mempengaruhi persepsi dan mulai mengevaluasi serta mengintepretasikannya. Setelah itu akan timbul sebuah persepsi sendiri. Dimana persepsi sendiri ini akan mempengaruhi periaku dan sikap dari masing-masing individu. Dari proses persepsi akan melahirkan hasil berupa perilaku tanggapan dan pembentukan sikap. Hasil dari perilaku tanggapan akan kembali pada stimulus, sedangkan hasil berupa pembentukan sikap akan kembali pada stimulus dan proses persepsi.

Pada penelitian ini, insentif merupakan situasi nyata didalam organisasi yang menyediakan ransangan, yang selanjutnya individu akan mulai mengobservasi rangsangan yang masuk yaitu insentif. Setelah individu memahami rangsangan yang masuk, individu akan mempertimbangkan faktor yang mempengaruhi persepsi dan mulai mengevaluasi serta mengintepretasikan persepsi tersebut sehingga akan timbul persepsi sendiri. Dimana persepsi sendiri akan membedakan persepsi dari tiap individu mengenai insentif. Hasil dari persepsi mengenai insentif pada penelitian ini ditampilkan oleh individu melalui perilaku, pada penelitian ini perilaku tersebut merupakan disiplin kerja.

Veitzal Rivai (2005:444) mengemukakan bahwa disiplin kerja adalah suatu alat yang digunakan para manajer untuk berkomunikasi dengan pegawai agar mereka bersedia untuk mengubah suatu perilaku serta sebagai suatu upaya untuk meningkatkan kesadaran dan kesediaan seseorang mentaati semua peraturan perusahaan dan norma-norma sosial yang berlaku.

Disiplin kerja atau kedisiplinan merupakan kesadaran dan kesediaan seseorang mentaati semua peraturan-peraturan perusahaan dan norma-norma sosial" (Hasibuan, 2007:193)

Berdasarkan uraian di atas, maka dapat ditarik kesimpulan bahawa adapun indikator yang dapat dijadikan variabel penelitian pada kajian ini, adalah:

1) Frekuensi kehadiran

2) Tingkat kewaspadaan

3) Ketaatan pada standar kerja

4) Ketaatan peraturan kerja

5) Etika kerja

Suatu organisasi harus memperhatikan disiplin kerja demi kelangsungan hidup organisasi karena disiplin kerja sangat berpengaruh terhadap prestasi kerja dan pada akhirnya akan dapat mempengaruhi pencapaian hasil/tujuan yang telah ditetapkan. Dalam mencapai disiplin kerja yang tinggi ada beberapa faktor yang mempengaruhi disiplin kerja menurut Gouzali Saydam (2005:291), antara lain :

a. Besar kecilnya pemberian kompensasi

b. Ada tidaknya keteladanan pimpinan dalam perusahaan

c. Ada tidaknya aturan pasti yang dapat dijadikan pegangan

d. Keberanian pimpinan dalam mengambil tindakan

e. Ada tidaknya pengawasan pimpinan

f. Ada tidaknya perhatian kepada para pegawai

g. Diciptakan kebiasaan-kebiasaan yang mendukung tegaknya disiplin. 
Dari pendapat di atas, terlihat bahwa disiplin kerja dipengaruhi oleh pemberian insentif, dimana yang telah dijelaskan oleh Anwar Prabu Mangkunegara (2002:89), mengemukakan bahwa: "Insentif adalah suatu bentuk motivasi yang dinyatakan dalam bentuk uang atas dasar kinerja yang tinggi dan juga merupakan rasa pengakuan dari pihak organisasi terhadap kinerja pegawai dan kontribusi terhadap organisasi (perusahaan)". Sehingga organisasi harus memperhatikan pemberian insentif kepada pegawai. Dengan kata lain, jika perusahaan tidak mampu menyediakan insentif, maka masihkah mereka mau meningkatkan prestasi dan masih maukah dia mentaati peraturan yang ada tanpa insentif yang berupa reward dan punishment. Dan pemberian insentif perlu dilakukan secara terancana dan berkesinambungan agar dapat terlaksana dengan baik. Sarwoto (2000:144) mengemukakan beberapa indikator- indikator insentif, yaitu:

1. Insentif material, dapat diberikan dalam bentuk :

a. Uang yang mencakup: bonus, komisi, profit sharing dan kompensasi yang ditangguhkan

b. Jaminan sosial yang biasanya diberikan dalam bentuk: pemberian rumah dinas, kendaraan, pengobatan secara gratis, cuti sakit dan melahirkan dengan tetap menerima gaji, pemberian tugas belajar (pendidikan dan pelatihan) dll.

2. Insentif non material, dapat diberikan dalam bentuk: pemeberian gelar (title) secara resmi, pemberian balas jasa, pemberian piagam penghargaan, pemberian promosi, pemberian hak untuk menggunakan suatu atribut dan fasilitas perusahaan, pemberian pujianatau ucapan terima kasih secara formal maupun informal.

Adapun pendapat lain mengenai indikator oleh Sondang P. Siagian (2002:269) yang daijadikan varibel dalam peleitian ini beberapa indikator- indikator insentif, yaitu:

1. Kinerja

2. Lama Kerja

3. Senioritas

4. Keadilan dan Kelayakn 
Gambar 1.4

Kerangka Pemekiran Pengaruh Insentif Terhadap Disiplin Kerja

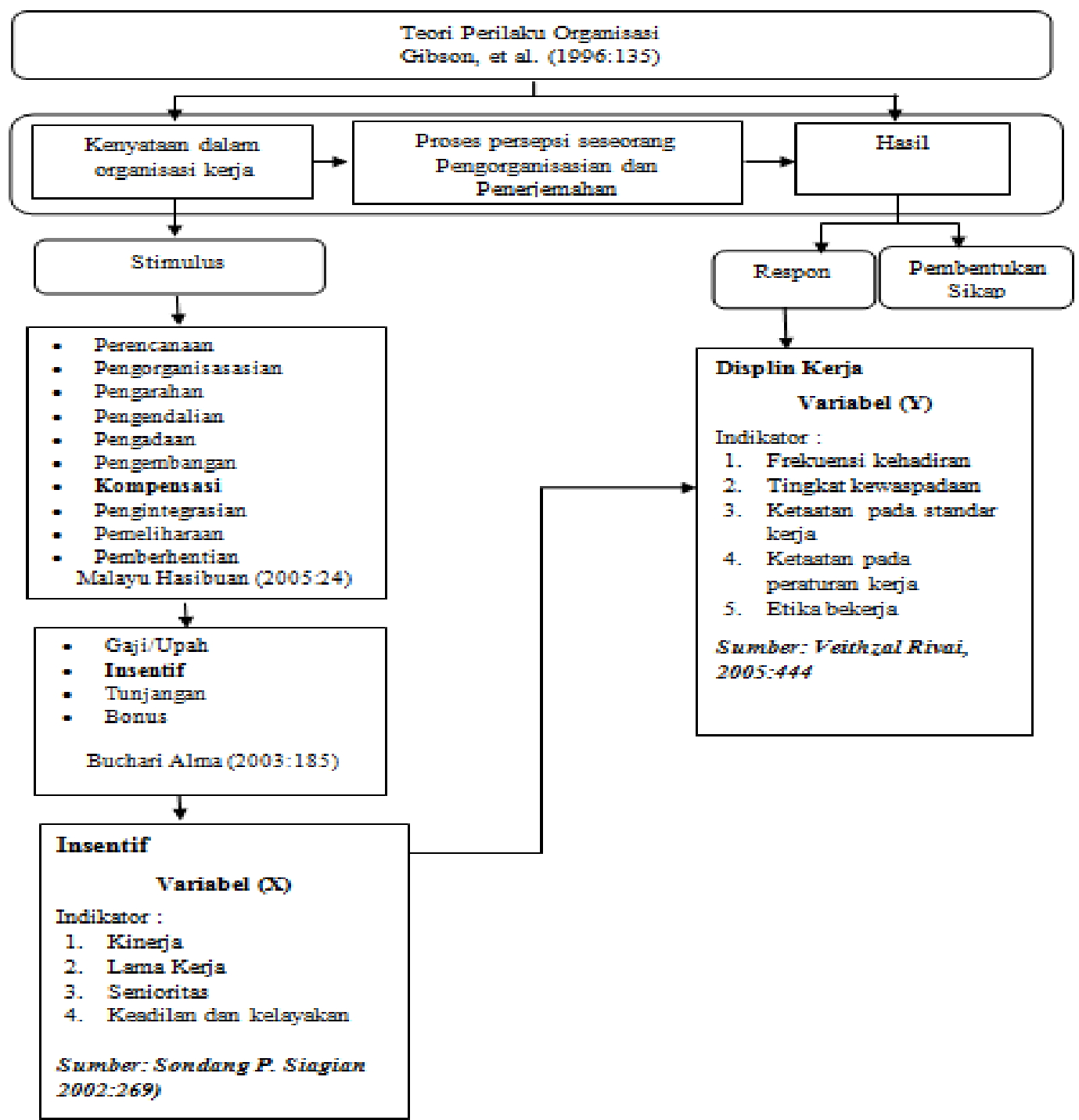

\section{METODE}

Metode dalam penelitian ini menggunkan metode survei eksplanasi. Metode survey eksplanasi digunakan untuk menjelaskan hubungan kausal antar dua variabel yang menggunakan kuesioner atau daftar pertanyaan yang ditujukan kepada responden sebagai alat pengumpulan data. Metode deskriptif digunkan untuk menggambarkan rumusan masalah nomor satu dan dua.

Penelitian ini terdiri dari dua variabel yaitu insentif (X) dan disiplin kerja pegawai (Y). Variabel insentif diukur melalui empat indikator yaitu: kinerja, lama kerja, senioritas dan keadilan dan kelayakan (Sondang P. Siagian, 2003:269). Sedangkan variabel disiplin kerja diukur melalui lima indikator yaitu: frekuensi kehadiran, tingkat kewaspadaan, ketaatan pada standar kerja, ketaatan pada peraturan kerja dan etika kerja (Veitzal Rivai,2005:444). 
Penelitian ini merupakan penelitian populasi, dimana seluruh pegawai Dinas Tenaga Kerja Kabupaten Bandung yang berjumlah 54 orang dijadikan responden.

Adapun pengujian instrumen dilakukan terhadap 20 orang responden di PT POS Indonesia Bandung, menggunakan uji validitas dan uji realibilitas dengan bantuan Microsoft Office Excel 2007.

Selanjutnya instrumen diuji dan disebar kepada responden asli dan dinyatakan valid dan reliabel. Maka berikutnya dilakukan uji persyaratan analisis data yaitu uji normalitas, uji linieritas dan uji homogenitas.

Teknik analisis data yang digunakan dalam penelitian kuantitatif adalah menggunakan teknik analisis data deskriptif dan inferensial. Tekinik analisis data deskriptif digunakan untuk menjawab rumusan masalah nomor satu dan dua yaitu mengenai gambaran efektivitas insentif dan tingkat disiplin kerja pegawai. Teknik analisis data inferansial digunkan untuk menjawab rumusan masalah nomor tiga yaitu adakah pengaruh positif pemberian insentif terhadap tingkat disiplin kerja pegawai Dinas Tenaga Kerja Kabupaten Bandung.

Dalam melakukan teknik analisis deskriptif variabel penelitian, untuk mempermudah digunakan kriteria tertentu untuk mengacu pada rata-rata skor kategori angket yang diperoleh dari responden.

Tabel 1.2

Skala Penafsiran Skor Rata-Rata

\begin{tabular}{|c|c|c|}
\hline \multirow{2}{*}{ Rentang } & \multicolumn{2}{|c|}{ Penafsiran } \\
\cline { 2 - 3 } & X & Y \\
\hline $1,00-1,79$ & Tidak Efektif & Rendah \\
\hline $1,80-2,59$ & Kurang Efektif & Cukup \\
\hline $2,6-3,39$ & Cukup Efektif & Tinggi \\
\hline $3,4-4,19$ & Efektif & Sangat Tinggi \\
\hline $4,2-5,00$ & Sangat Efektif & . \\
\hline
\end{tabular}

Sumber: Diadaptasi dari skor kategori likert skala 5 (Sambas dan Maman 2007:146)

Pengujian hipotesis digunkan untuk mengetahui apakah terdapat hubungan yang cukup jelas dan dipercaya anatara variabel independen dan dependen. Melalui pengujian hipotesis ini akan diambil kesimpulan menerima atau menolak hipotesis.

Menurut Sambas Ali Muhidin (2010:43), prosedur pengujian hipotesis ini melipti beberapa langkah yaitu:

1. Menentukan rumusan hipotesis $\mathrm{H}_{0}$ dan $\mathrm{H}_{1}$

$H_{0}: \beta=0 \quad$ : Tidak ada pengaruh insentif terhadap disiplin kerja pegawai Dinas Tenaga Kerja Kabupaten Bandung

$H_{1}: \beta \neq 0 \quad:$ Terdapat pengaruh insentif terhadap disiplin kerja pegawai Dinas Tenaga Kerja Kabupaten Bandung

2. Membuat Persamaan Dan Koefisien Regresi Sederhana. Model persamaan regresi adalah $\hat{Y}=a+b X$

3. Menentukan uji statistika yang sesuai. Uji statistik yang digunkan adalah uji $\mathrm{F}$, yaitu $F$ $=\frac{s_{1}^{2}}{s_{2}^{2}}$.

4. Membandingkan nilai uji $F$ terhadap nilai $F_{\text {tabel }}=\mathrm{F}_{(1-\mathrm{a})}\left(\mathrm{d} \mathrm{b}_{\mathrm{reg}(\mathrm{b} \mid \mathrm{a})}\left(\mathrm{db}_{\mathrm{res}}\right)\right.$

5. Membuat kesimpulan. 
Untuk mengetahui hubungan anatara variabel $\mathrm{X}$ dengan variabel $\mathrm{Y}$ dicari dengan menggunkan rumus koefisien korelasi. Koefisien korelasi dalam penelitian ini menggunkan Korelasi Product Moment yang dikembangkan oleh Karl Pearson (Sambas Ali Muhidin 2010:26), seperti berikut:

$$
\mathrm{r}_{x y}=\frac{N \sum X Y-\left(\sum X\right) \cdot\left(\sum Y\right)}{\sqrt{\left[N \sum X^{2}-\left(\sum X\right)^{2}\right] \cdot\left[N \sum Y^{2}-\left(\sum Y\right)^{2}\right]}}
$$

Selanjutnya untuk megetahui besarnya pengaruh variabel $\mathrm{X}$ terhadap variabel $\mathrm{Y}$, maka digunakan koefisien determinasi $(\mathrm{KD})$ dengan rumus:

$$
\mathrm{KD}=\mathrm{r}^{2} \times 100 \%
$$

\section{HASIL DAN PEMBAHASAN}

Variabel dalam penelitian ini meliputi dua variabel, yaitu Insentif (X) dan Disiplin Kerja Pegawai (Y). Variabel insentif diukur melalui empat indikator dengan menggunakan 11 item pernyataan. Maka diperoleh hasil sebagai berikut:

\section{Tabel 1.3}

\section{Rekapitulasi Tanggapan Responden Variabel Pemberian Insentif}

\begin{tabular}{|l|c|c|c||}
\hline \multicolumn{4}{|c||}{ Variabel Pemberian Insentif } \\
\hline \multicolumn{1}{|c|}{ Indikator } & Item & Rata-rata & Kategori \\
\hline Kinerja & $1-3$ & 3,87 & Efektif \\
\hline LamaKerja & $4 \cdot 5$ & 3,80 & Efektif \\
\hline Senioritas & $6-8$ & 3,83 & Efektif \\
\hline Keadilan dan Kelayglan & $9 \cdot 11$ & 3,78 & Efektif \\
\hline \multicolumn{4}{|c|}{ Rata-rata } \\
\hline
\end{tabular}

Sumber: Hasil Pengolahan Data

Dari tabel diatas, menujukkana bahwa rata-rata skor jawaban responden variaebel pemebrian insentif sebesar 3,84. Apabila dihubungkan dengan skala penafsiran pada tabel rekapitulasi skor kriterium, maka angka tersebut berada pada rentang 3,4 - 4,1 dengan kategori efektif. Hasil dari tabel tersebut diperoleh melalui hitungan presentase terhadap skor jawaban responden, seperti pada diagaram berikut:

Gambar 1.5

Skor Rata-rata setiap Indikator Variabel Insentif

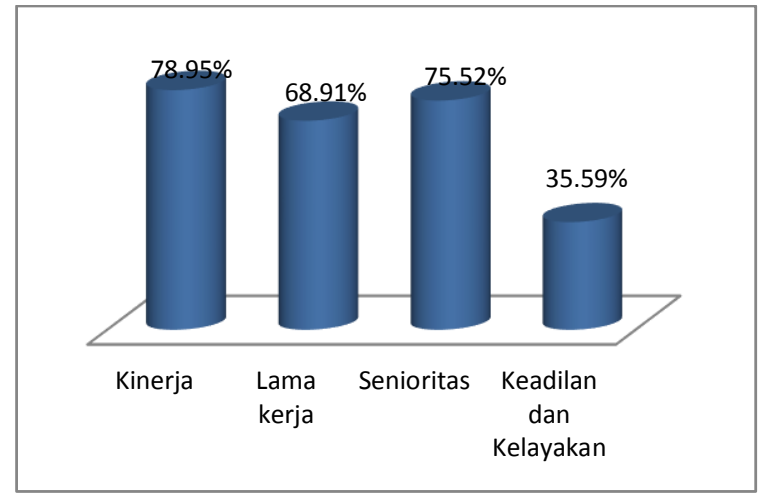

Sumber: Skor Jawaban Responden 
Berdasarkan diagram di atas menunjukkan indikator "Kinerja" memiliki rata-rata indikator dan perhitungan presentase tertinggi yaitu sebesar 78,95\%. Sedangakan rata-rata indikator dan perhitungan presentase terendah yaitu pada indikator "Keadilan dan kelayakan" sebesar 35,59\%.

Permasalahan pertama yang ingin diketahui dalam penelitian ini adalah “Bagaimana gamabaran efektivitas insentif di Dinas Tenaga Kerja Kabupaten Bandung?".

Berdasarkan penjelasan di atas dapat diketahui efektivitas insentif di Dinas Tenaga Kerja Kabupaten Bandung berada pada kategori efektif, yaitu presenatse sebesar 3,84.

Permasalahan kedua yang ingin diketahui dalam penelitian ini adalah "Bagaimana gamabaran tingkat disiplin kerja pegawai di Dinas Tenaga Kerja Kabupaten Bandung?".

Variabel Disiplin Kerja Pegawai diukur berdasarkan lima indikator. Kelima indikator tersebut diuraikan menjadi 16 item pernyataan. Maka diperoleh hasil sebagai berikut:

Tabel 1.4

Rekapitulasi Tanggapan Responden Variabel Displin Kerja Pegawai

\begin{tabular}{|l|c|c|c|}
\hline \multicolumn{1}{|c|}{ Indikator } & Item & Rata-rata & Kategori \\
\hline Frekuensi Kehadiran & $1-4$ & 3,98 & Tinggi \\
\hline Tingkat Kewaspadaan & $5-8$ & 4,00 & Tinggi \\
\hline Ketaatan Pada Standar Kerja & $9-10$ & 3,82 & Tinggi \\
\hline $\begin{array}{l}\text { Ketaatan Pada Peraturan } \\
\text { Kerja }\end{array}$ & $11-13$ & 3,73 & Tinggi \\
\hline Etika Kerja & $14-16$ & 3,83 & Tinggi \\
\hline \multicolumn{2}{|r|}{ Rata-rata } \\
\hline
\end{tabular}

Sumber : Hasil Pengolahan Data

Berdasarkan tabel diatas, menujukkan bahwa rata-rata indikator variabel Disiplin Kerja pegawai yaitu sebesar 3,85. Apabila dilihat dari skala penafsiran pada tabel tabel rekapitulasi skor kriterium, maka angka tersebut berada pada rentang 3,4-4,1 dengan kategori efektif. Berdasarkan hasil perhitungan variabel indikator disiplin kerja pegawai diperoleh melalui hitungan presentase terhadap skor jawaban responden pada diagram berikut: 


\section{Gambar 1.6}

\section{Skor Rata-rata setiap Indikator Variabel Disiplin Kerja Pegawai}

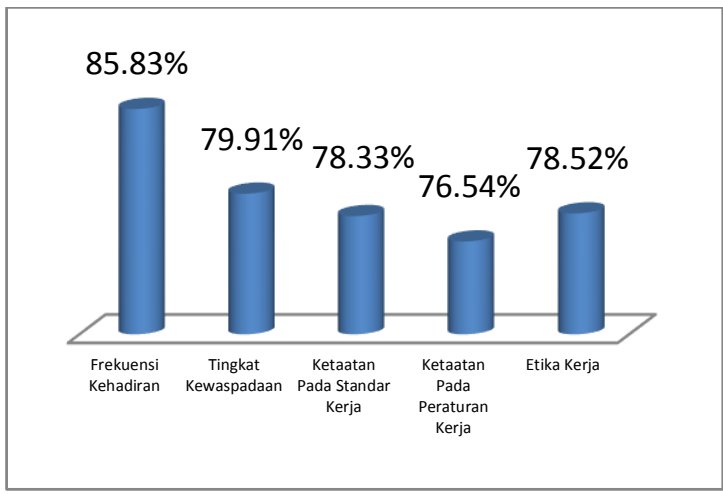

Sumber: Skor Jawaban Responden

Berdasarkan diagram di atas menujukkan indikator "Frekuensi Kehadiran" memiliki rata-rata indikator dan perhitungan presentase tertinggi yaitu sebesar 85,83\%. Indikator "Ketaatan pada Peraturan Kerja" memiliki rata-rata indikator terendah yaitu sebesar $76,54 \%$.

Permasalahan selanjutnya yang ingin diketahui adalah "Seberapa besar pengaruh efektivitas insentif terhadap disiplin kerja pegawai Dinas Tenaga Kerja Kabupaten Bandung?”.

Peneliti melakukan uji statistik, setelah diketahui bahwa data penelitian berdistribusi normal dan linier, kemudian peneliti menggunakan statistik parametrik dalam menguji hipotesis penelitian.

Pengujian hipotesis dilakukan bertujuan untuk membuat kesimpulan bahwa variabel insentif memberikan pengaruh positif terhadap variabel disiplin kerja pegawai di Dinas Tenaga Kerja Kabupaten Bandung, artinya tinggi rendahnya variabel disiplin kerja pegawai dipengaruhi oleh pemberian insentif.

Berdasarkan perhitungan hipotesis diperoleh nilai $F_{\text {hitung }}$ sebesar 21,112 sedangkan $\mathrm{F}_{\text {tabel }}$ dengan tingkat kesalahan $a=0,005 ; \mathrm{dk}_{\text {reg }(\mathrm{b} / \mathrm{a})}=1$ dan $\mathrm{dk}_{\text {res }}=\mathrm{n}-2=54-2=52$ sebesar 4,027, artinya $F_{\text {hitung }}>F_{\text {tabel }}(21,112>4,027)$ dengan nilai positif, maka $\mathrm{H}_{0}$ di tolak dan $\mathrm{H}_{1}$ diterima. Sehingga dapat disimpulkan bahwa "Insentif berpengaruh secara positif dan signifikan terhadap Disiplin Kerja Pegawai di Dinas Tenaga Kerja Kabupaten Bandung.

Berdasarkan hasil perolehan data diperoleh nilai koefisien korelasi antara variabel Insentif (X) dan Disiplin Kerja Pegawai (Y) sebesar 0,537, apabila dilihat dari tabel kriteria interpretasi koefisien korelasi nilai 0,537 berada pada rentang nilai 0,400 sampai dengan 0,599 yang termasuk dalam kategori "sedang atau cukup kuat". Sehingga dapat disimpulkan bahwa terdapat hubungan yang cukup kuat antara variabel Insentif (X) dan Disiplin Kerja Pegawai (Y) Dinas Tenaga Kerja Kabupaten Bandung.

Hal tersebut sesuai dengan interpretasi nilai koefisien korelasi, pada tabel berikut: 
Tabel 1.5

Kriteria Interpretasi Koefisien Korelasi

\begin{tabular}{|l|c|}
\hline \multicolumn{1}{|c|}{ Besar $\mathrm{r}_{\mathrm{xy}}$} & Interpretasi \\
\hline Antara 0,000 sampai 0,199 & Sangat Rendah \\
\hline Antara 0,200 sampai 0,399 & Rendah \\
\hline Antara 0,400 sampai 0,599 & Sedang/Cukup Kuat \\
\hline Antara 0,600 sampai 0,799 & Kuat/Tinggi \\
\hline Antara 0,800 sampai 0,999 & Sangat Kuat/Tinggi \\
\hline
\end{tabular}

Sumber: Sugiyono $(2011: 183)$

Berdasarkan hasil perolehan perhitungan di atas nilai koefisien determinasi variabel insentif (X) terhadap disiplin kerja pegawai (Y) yaitu sebesar $28,88 \%$. Artinya variabel Disiplin Kerja Pegawai dipengaruhi oleh variabel Insentif sebanyak 28,88\% dan sisanya $71,12 \%$ dipengaruhi oleh faktor lain yang tidak diteliti.

Secara empirik, hasil penelitian meginformasikan bahwa insentif berpengaruh secara signifikan terhadap peningkatan disiplin kerja pegawai sebesar $28,88 \%$. Hasil ini menujukkan bahwa insentif merupakan salahsatu faktor yang dapat mempengaruhi dan meningkatan disiplin kerja pegawai.

Hasil penelitian ini memberikan informasi bahwa insentif berpengaruh positif dan signifikan terhadap disiplin kerja pegawai.

\section{KESIMPULAN}

1. Gambaran variabel insentif di Dinas Tenaga Kerja Kabupaten Bandung, yang diukur dari empat indikator berada pada kategori efektif.

2. Gambaran disiplin kerja pegawai di Dinas Tenaga Kerja Kabupaten Bandung, terdiri dari lima indikator berada pada kategori tinggi.

3. Insentif berpengaruh posif dan signifikan terhadap disiplin kerja pegawai di Dinas Tenaga Kerja Kabupaten Bandung. Besarnya pengaruh insentif (X) terhadap disiplin kerja (Y) tergolong sedang/cukup kuat.

\section{DAFTAR PUSTAKA}

Dessler, Garry (2007).Manajemen sumber daya manusia: edisi kesepuluh jilid 2. Jakarta: PT indeks

Fathoni, Abdurrahmat (2006). Manajemen Sumber Daya Manusia. Jakarta: PT. Rineka Cipta

Gibson, et al. (2006).Organisasi: Perrilaku, Struktur dan Proses. Alih Bahasa: Nunuk Adriani. Jakarta: Erlangga.

Hariandja, Marihot T.E. (2002). Manajemen Sumber Daya Manusia:Pengadaan, Pengembangan, Pengompensasian Dan Peningkatan Produktivitas Pegawai. Jakarta: Grasindo.

Hasibuan, Malayu S.P. (2009). Manajemen Sumber Daya Manusia: Edisi Revisi. Jakarta: Bumi Aksara 
Riva'i, Veithzal. (2013). Manajemen sumber Daya Manusia Untuk Perusahaan: Dari Teori Ke Praktik. Edisi 2.Jakarta: Rajagrafindo

Sarwoto (2000).Dasar-Dasar Organisasi Dan Manajemen. Jakarta: Ghalia Indonesia.

Sastradipoera, Komaruddin. (2007). Manajemen Sumber Daya Manusia: Suatu Pendekatan Fungsi Operatif. Bandung: Kappa-Sigma Bandung

Saydam, Gouzali. (2005). Manajemen Sumber Daya Manusia: Suatu Pendekatan Mikro. Jakarta: Djambatan.

Sinungan, Muchdarsyah. (2003). Produktivitas: Apa dan Bagaimana. Jakarta: Bumi Aksara.

Siswanto, Bedjo. (2005). Manajemen Tenaga Kerja: Pendekatan Administratif dan Operasional. Jakarta: Bumi Aksara. 